\title{
Food Neophobia in Preschool Children
}

\author{
DALIA DOP*, ELENA CARMEN NICULESCU \\ University of Medicine and Pharmacy, Department of Pediatrics, 2nd Petru Rares Str., 200349, Craiova, Romania
}

Food neophobia is generally considered as the reluctance to eat or the avoidance of new foods. Neophobia is not a permanent aversion to new food; acceptance can be promoted by repeated exposure or modeling the intake of the rejected food product.The study followed a number of 168 children aged between 2 and 5 years. The parents of the children filled a questionnaire regarding the physiological medical data of the children, the feeding habits (quantitative and qualitative). Neophobia was measured using the Child Food Neophobia Scale (CFNS). The study pursued the association between neophobia and the sex of the patient, the quality of the food products, the children's diet (presence of fruits, vegetables), the weight of the patients, the duration of breastfeeding, the education level of the mother. Girls present higher scores on the CFNS scale than the boys. Children whose mothers have higher education were susceptible to having a higher variety of fruits in their diet. Children with a higher score on the CFNS scale and those with siblings were susceptible to having a lower variety of fruits and dairy products in their diet and a higher intake of fast-food products. The results highlight the necessity for early exposure of the children to a high variety of nutrient foods and the need to educate the parents with regard to the strategies needed in order to overcome food neophobia.

Keywords: food neophobia, preschool children, Child Food Neophobia Scale

Food neophobia is generally considered as the reluctance to eat or the avoidance of new foods, which can result in restricted feeding habits [1]. Neophobia somewhat overlaps the group of fussy-agitated eaters, who consume a variety of inadequate foods by rejecting both familiar and unfamiliar food products. There numerous variables that influence the onset of eating disorders: age, personality, social influences, parental feeding practices, environment and culture. In the case of neophobia, the acceptance of new foods can be promoted by repeated exposure to the food or modeling the intake of the rejected food product. Unlike neophobia, the period cannot be overcome in fussy-agitated eaters by repeated exposure to foods [2].

There are numerous instruments to determine neophobia, some adapted to age groups (Food Situation Questionnaire (FSQ), Food Neophobia Questionnaire (FNQ), Teacher-administered Taste-Test Tool (TTT) and WillTry Instrument, Food Attitude Scale (FAS), Variety Seeking Tendency Scale (VARSEEK) etc) [3]. One the instruments that are most used at this moment in order to evaluate neophobia and the desire to try unfamiliar aliments is the Child Food Neophobia Scale (CFNS), developed by Pliner and Hobden (1994), which we have also used in our study. CFNS was used on a large scale and it has provided reliable results [4-6].

The aim of this study was to determine the presence of food neophobia in preschool children and its correlation with the personal physiological characteristics of the children and of the family and with the children's diet.

\section{Experimental parts \\ Material and method}

The study followed 168 children aged between 2 and 5 years, who were hospitalized in the $1^{\text {st }}$ Pediatrics clinic of the District Emergency Hospital of Craiova with acute diseases and who were not registered with allergies. The children's parents filled a questionnaire regarding the physiological medical data of the children, feeding habits (quantitative and qualitative). The study pursued the association between neophobia and the sex of the patient, the quality of the food products, the children's diet (intake of fruits, vegetables, meat), the weight of the patients, the duration of breastfeeding, food diversification, the education level of the mother, the marital status, the presence of neophobia in one of the parents.

Neophobia was measured using the Child Food Neophobia Scale (CFNS) (Pliner P 1994), adapted to the age group by removing the items which do not correspond to the age of the child (e.g., ethnic food looks ugly to me). This calculating instrument was validated, showing good internal consistency. The scale contains 6 questions: My child doesn't trust new foods; If my child doesn't know what is in a food, (s)he won't try it; My child is afraid to eat things (s)he has never had before; My child will eat almost anything (inversed score); My child is very particular about the foods (s)he will eat; My child is constantly sampling new and different foods (inversed score), in which parents give

*email: dalia_tastea@yahoo.com 
scores ranging from 1 to 4 , where 1 means "I don't agree", and 4 means "I strongly agree". Thus the high scores indicate a high parental perception for the presence of neophobia in children.

The analysis of the data was carried out with the help of IBM SPSS version 22. Covariates were selected from the characteristics of the mother and child, in order to include them in the regression models based on a significant association $(\mathrm{p} \leq 0.05)$, with at least one of the consequent variables.

\section{Results and discussions}

Table 1

GENERAL CHARACTERISTICS OF THE CHILDREN AND MOTHERS IN THE STUDY

\begin{tabular}{|c|c|c|}
\hline Child's characteristics & Range & Average \\
\hline Age (years) & $2.4-5$ & $3.6 \pm 0.6$ \\
\hline Weight at birth (g) & $2300-4100$ & $3001.08 \pm 285.6$ \\
\hline Current weight (kg) & $12-22$ & $16.5 \pm 1.9$ \\
\hline Boys & - & 97 \\
\hline Breastfeeding (months) & $0-14$ & $5 \pm 2.6$ \\
\hline Diversification (months) & $4-7$ & $5.8 \pm 0.7$ \\
\hline Mother's characteristics & & $28.14 \pm 5$ \\
\hline Mother's age (years) & $17-44$ & 149 \\
\hline Marital status & - & 71 \\
\hline Multiparous & - & $\%$ \\
\hline Level of education & frequent & 4.2 \\
\hline illiterate & 7 & 10.1 \\
\hline college & 17 & 19.0 \\
\hline middle school & 32 & 50.6 \\
\hline high school & 85 & 4.8 \\
\hline post-secondary school & 8 & 11.3 \\
\hline elementary & 19 & \\
\hline
\end{tabular}

The study followed a number of 168 children $(97 \mathrm{~F}-57.7 \% ; 71 \mathrm{M}-42.3 \%)$. The age of the subjects ranged from 2.4 to 5 years, with a global average of 3.6 years \pm 0.6 years, slightly higher in girls (3.6 years vs. 3.5 years). The weight at birth $(\mathrm{g})$ varied from 2300 to $4100 \mathrm{~g}$, on average $3001.8 \pm 285.6 \mathrm{~g}$, significantly higher $(\mathrm{p}=0.001)$ for boys (3088.3 g vs. $2938.5 \mathrm{~g}$ ). The current weight $(\mathrm{kg})$ varied from 12 to $22 \mathrm{~kg}$, on average $16.5 \pm 1.9 \mathrm{~kg}$, with no significant differences between sexes (boys $-16.7 \mathrm{~kg}$ vs. $16.3 \mathrm{~kg}$ girls) (Table 1).

Breastfeeding lasted for up to 14 months, the average being $5 \pm 2.6$ months, significantly higher $(\mathrm{p}=0.009)$ for boys (cca. 6 months vs. 4.5 months girls). Food diversification started between 4 and 7 months, without significant differences between sexes $(5.8 \pm 07$ months, $\mathrm{p}>0.05)$. Mother's level of education did not influence the moment of food diversification (Table 1).

Mother's age varied between 17 and 44 years, with an average of $28.14 \pm 5$ years, without significant differences between sexes. The "married" status was reported by a number of 149 mothers (cca. 89\%). As far as the level of education is concerned, the most predominant was high school, cca. $51 \%$ of the mothers having graduated this type of studies.

As far as the children's diet is concerned, meat is consumed daily by $79.8 \%$ of the children, vegetables by $83.3 \%$, dairy products by $86.9 \%$, and fruits by $32.7 \%$ of the children (Table 2 ).

Table 2

CHILDREN 'S DIET BY FOOD GROUPS

\begin{tabular}{|c|c|r|r|}
\hline \multicolumn{2}{|c|}{} & \multicolumn{1}{|c|}{$\begin{array}{c}\text { Children } \\
\text { frequency }\end{array}$} & \multicolumn{1}{c|}{$\%$} \\
\hline \multirow{2}{*}{$\begin{array}{c}\text { Consumption } \\
\text { frequency } \\
\text { meat }\end{array}$} & 3/week & 14 & 8.3 \\
\cline { 2 - 4 } & 4/week & 20 & 11.9 \\
\cline { 2 - 4 } & daily & 134 & 79.8 \\
\cline { 2 - 4 } & Total & 168 & 100.0 \\
\hline \multirow{2}{*}{$\begin{array}{c}\text { Consumption } \\
\text { cereals }\end{array}$} & yes & 98 & 58.3 \\
\cline { 2 - 4 } & no & 70 & 41.7 \\
\cline { 2 - 4 } & Total & 168 & 100.0 \\
\hline \multirow{2}{*}{$\begin{array}{c}\text { Consumption } \\
\text { frequency } \\
\text { dairy products }\end{array}$} & 1/week & 1 & 0.6 \\
\cline { 2 - 4 } & 2/week & 4 & 2.4 \\
\cline { 2 - 4 } & 3/week & 12 & 7.1 \\
\cline { 2 - 4 } & 4/week & 5 & 3.0 \\
\cline { 2 - 4 } & daily & 146 & 86.9 \\
\hline
\end{tabular}




\begin{tabular}{|l|l|r|r|}
\hline & Total & 168 & 100.0 \\
\hline \multirow{4}{*}{$\begin{array}{l}\text { Consumption } \\
\text { frequency fruits }\end{array}$} & 1/week & 1 & 0.6 \\
\cline { 2 - 4 } & 2/week & 11 & 6.5 \\
\cline { 2 - 4 } & 3/week & 54 & 32.1 \\
\cline { 2 - 4 } & 4/week & 47 & 28.0 \\
\cline { 2 - 4 } & daily & 55 & 32.7 \\
\cline { 2 - 4 } & Total & 168 & 100. \\
\hline \multirow{3}{*}{$\begin{array}{l}\text { Consumption } \\
\text { frequency } \\
\text { vegetables }\end{array}$} & 3/week & 12 & 0 \\
\cline { 2 - 4 } & 4/week & 15 & 8.1 \\
\cline { 2 - 4 } & 5/week & 1 & 0.9 \\
\cline { 2 - 4 } & daily & 140 & 83.3 \\
\cline { 2 - 4 } & Total & 168 & 100. \\
& & & 0 \\
\hline
\end{tabular}

The CFNS score varied between 6 and 23, with an average of $14.5 \pm 3.9$ (Table 3). The variation was significant between sexes $(\mathrm{p}=0.000)(16.1 \pm 3.4 \mathrm{~F}$ vs. $12.3 \pm 3.5 \mathrm{M})$ and in relation to the level of education $(\mathrm{p}=0.000)$, the maximum score being registered for children whose mothers had no studies $(20 \pm 2.6)$, the minimum score for children whose mothers had college studies $(12.2 \pm 3.3)$. Statistically significant differences in the CFNS score were registered in relation to the presence and number of siblings $(p=0.010)$, the minimum score was registered for those without brothers/sisters ( $14 \pm 3.6$ vs. $18.3 \pm 2.1$ for $2-/ 3$ siblings). We did not register any significant association between the CFNS score and children's weight at birth, breastfeeding or the moment when solid foods were introduced.

Overall, slight positive correlations were registered with the child's age $(r=0.273, p=0.000)$ (Table 3) and the presence of siblings $(r=0.223, p=0.004)$ (Table no. 4). Furthermore, neophobia scores are higher in children whose mothers have a low level of education $(r=-0.493, p=0.00)($ Table 4$)$ or one of the parents is neophobic $(r=0.483, p$ $=0.004)$; CFNS is higher in the case of parents with neophobia $(19.2 \pm 2.1$ mother vs. $18.6 \pm 3$ father, vs. $13.6 \pm 3.5$ children with parents without neophobia). Indirectly, CFNS is associated with low consumption of fruits $(\mathrm{r}=-0.514, \mathrm{p}$ $=0.000)$ and dairy products $(\mathrm{r}=-0.161, \mathrm{p}=0.038)$ and high consumption of fast-food products $(\mathrm{r}=0.483, \mathrm{p}=0.000)$. (Table 5)

Table 3

CORRELATIONS ASSOCIATED TO THE CHILD OVERALL

\begin{tabular}{|c|c|c|c|c|c|c|}
\hline \multicolumn{2}{|c|}{} & age & $\begin{array}{c}\text { W at } \\
\text { birth }\end{array}$ & Current W & $\begin{array}{c}\text { Breast- } \\
\text { feeding }\end{array}$ & $\begin{array}{c}\text { diversificati } \\
\text { on }\end{array}$ \\
\hline \multirow{3}{*}{ CFNS score } & r-correlation coefficient & $0.273^{* *}$ & -0.078 & 0.148 & 0.066 & 0.033 \\
\cline { 2 - 7 } & $p$ & 0.000 & 0.317 & 0.055 & 0.397 & 0.668 \\
\cline { 2 - 7 } & Number of subjects & 168 & 168 & 168 & 168 & 168 \\
\hline
\end{tabular}

Table 4

CORRELATIONS ASSOCIATED TO THE FAMILY OVERALL

\begin{tabular}{|c|c|c|c|c|c|c|}
\hline \multicolumn{2}{|c|}{} & \multirow{2}{*}{ mother's age } & education & married & siblings & $\begin{array}{c}\text { Parents with } \\
\text { neophobia }\end{array}$ \\
\hline \multirow{2}{*}{ CFNS score } & $\begin{array}{c}\mathrm{r} \text { - correlation } \\
\text { coefficient }\end{array}$ & 0.073 & $-0.493^{* *}$ & -0.022 & $0.223^{* *}$ & $0.492^{* *}$ \\
\cline { 2 - 7 } & $\mathrm{p}$ & 0.350 & 0.000 & 0.774 & 0.004 & 0.000 \\
\cline { 2 - 7 } & Number of subjects & 168 & 168 & 168 & 168 & 168 \\
\hline
\end{tabular}

Table 5

CORRELATIONS ASSOCIATED TO THE QUALITY OF THE CHILD’S DIET/OVERALL

\begin{tabular}{|c|c|c|c|c|c|c|c|}
\hline \multicolumn{2}{|c|}{} & fruits & vegetables & meat & $\begin{array}{c}\text { dairy } \\
\text { products }\end{array}$ & sweets & fast-food \\
\hline \multirow{2}{*}{$\begin{array}{c}\text { CFNS } \\
\text { score }\end{array}$} & $\mathrm{r}-$ correlation coefficient & $-0.514^{* *}$ & 0.060 & -0.138 & $-0.161^{*}$ & -0.027 & $0.483^{* *}$ \\
\cline { 2 - 8 } & $\mathrm{p}$ & 0.000 & 0.443 & 0.075 & 0.038 & 0.728 & 0.000 \\
\cline { 2 - 8 } & Number of subjects & 168 & 168 & 168 & 168 & 168 & 168 \\
\hline
\end{tabular}

When the analysis was layered taking into consideration gender composition, the relation was highlighted only for girls (CFNS - age $r=0.408, p=0.000$; CFNS - siblings $r=0.231, p=0.023$ )

In girls we highlighted a weak positive relation to the duration of breastfeeding $(r=0.220, p=0.030$ ), children's current weight, $(r=0.344, p=0.001)$ (Table 6), presence of siblings $(r=0.231, p=0.023)$ and an intense inversed relation to the mother's level of education $(r=-0.640, p=0.000)$ (Table 7). Thus, the high neophobia scores of the girls are associated to longer breastfeeding, larger current weight, the presence of a sibling and a lower level of 
education of the mother. For the boys, we highlighted a weak inversed relation to the mother's level of education $(\mathrm{r}=-$ $0.234, \mathrm{p}=0.049)$

Children's neophobia is correlated with the parents' neophobia in both sexes, but especially in the case of the girls $(\mathrm{r}=0.508, \mathrm{p}=0.00)($ Table 7$)$.

The CNFS analysis in relation to the quality of the diet (Table no. 8) highlighted a medium positive connection to the habit of fast-food consumption $(r=0.483, p=0.000)$ and respectively a medium negative connection to the habit of fruits consumption $(\mathrm{r}=-0.514, \mathrm{p}=0.000)$. Thus, children with high neophobia scores consume less fruits and more fast-food products. Furthermore, girls with neophobia consume less dairy products $(r=-0.259, p=0.010)$, while neophobic boys consume less sweets $(r=-0.335, p=0.04)$.

Table 6

CORRELATIONS ASSOCIATED TO THE CHILD / BATCHES BY SEX

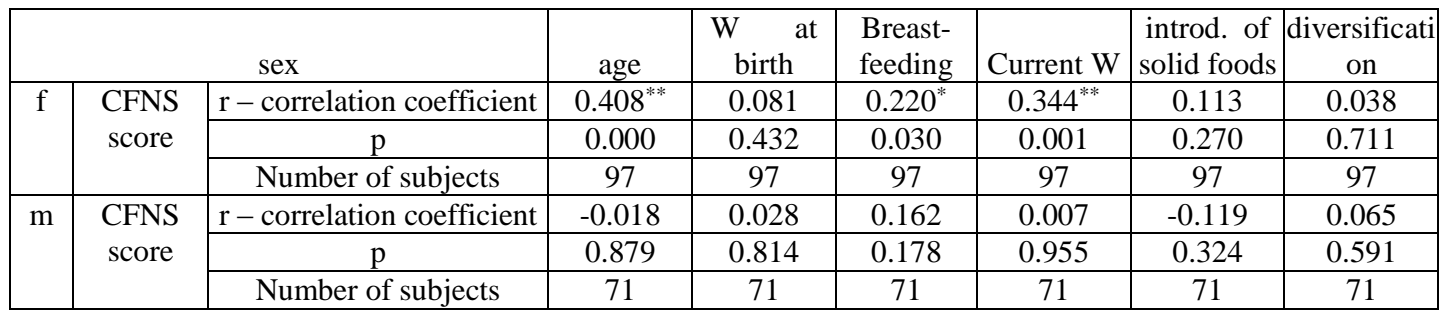

Table 7

CORRELATIONS ASSOCIATED TO THE FAMILY / BATCHES BY SEX

\begin{tabular}{|c|c|c|c|c|c|c|c|}
\hline \multicolumn{3}{|c|}{ sex } & \multirow{2}{*}{$\begin{array}{c}\text { mother's age } \\
0.025\end{array}$} & \multirow{2}{*}{$\begin{array}{l}\text { education } \\
-0.640^{* *}\end{array}$} & \multirow{2}{*}{$\begin{array}{l}\text { married } \\
-0.049\end{array}$} & \multirow{2}{*}{$\begin{array}{l}\text { siblings } \\
0.231^{*}\end{array}$} & \multirow{2}{*}{$\begin{array}{c}\begin{array}{c}\text { Parents with } \\
\text { neophobia }\end{array} \\
0.508^{* *}\end{array}$} \\
\hline $\mathrm{f}$ & CFNS score & $\mathrm{r}$ - correlation coefficient & & & & & \\
\hline & & $\mathrm{p}$ & 0.806 & 0.000 & 0.631 & 0.023 & 0.000 \\
\hline & & Number of subjects & 97 & 97 & 97 & 97 & 97 \\
\hline \multirow[t]{3}{*}{$\mathrm{m}$} & \multirow[t]{3}{*}{ CFNS score } & $\mathrm{r}$ - correlation coefficient & 0.049 & $-0.234^{*}$ & -0.042 & 0.008 & $0.315^{* *}$ \\
\hline & & $\mathrm{p}$ & 0.687 & 0.049 & 0.726 & 0.949 & 0.008 \\
\hline & & Number of subjects & 71 & 71 & 71 & 71 & 71 \\
\hline
\end{tabular}

Table 8

CORRELATIONS ASSOCIATED TO THE QUALITY OF THE CHILD'S DIET / BATCHES BY SEX

\begin{tabular}{|c|c|c|c|c|c|c|c|c|}
\hline \multicolumn{3}{|c|}{ sex } & fruits & vegetables & meat & $\begin{array}{c}\text { dairy } \\
\text { products }\end{array}$ & sweets & fast-food \\
\hline \multirow[t]{3}{*}{$\mathrm{f}$} & \multirow[t]{3}{*}{ CFNS score } & $\mathrm{r}$ - correlation coefficient & $-0.521^{* *}$ & 0.000 & $-0.226^{*}$ & $-0.259^{*}$ & 0.187 & $0.554^{* *}$ \\
\hline & & $\mathrm{p}$ & 0.000 & 0.999 & 0.026 & 0.010 & 0.067 & 0.000 \\
\hline & & Number of subjects & 97 & 97 & 97 & 97 & 97 & 97 \\
\hline \multirow[t]{3}{*}{$\mathrm{m}$} & \multirow[t]{3}{*}{ CFNS score } & $\mathrm{r}$ - correlation coefficient & $-0.315^{* *}$ & -0.072 & -0.127 & 0.036 & $-0.335^{* *}$ & $0.256^{*}$ \\
\hline & & $\mathrm{p}$ & 0.007 & 0.553 & 0.290 & 0.764 & 0.004 & 0.031 \\
\hline & & Number of subjects & 71 & 71 & 71 & 71 & 71 & 71 \\
\hline
\end{tabular}

Table 9

QUALITY OF DIET IN RELATION TO THE PRESENCE OF NEOPHOBIA AMONG THE PARENTS

\begin{tabular}{|c|c|c|c|c|c|c|c|}
\hline \multicolumn{8}{|c|}{ DIET } \\
\hline \multicolumn{2}{|c|}{ Parents' neophobia } & $\begin{array}{c}\text { Fruits } \\
\mathrm{p}=0.000\end{array}$ & vegetables & meat & dairy products & sweets & $\begin{array}{c}\text { fast-food } \\
\mathrm{p}=0.000\end{array}$ \\
\hline \multirow[t]{3}{*}{0} & Mean & 4.78 & 6.46 & 6.39 & 6.51 & 6.96 & 0.038 \\
\hline & \begin{tabular}{|l|} 
Std. Deviation \\
\end{tabular} & 1.824 & 1.257 & 1.315 & 1.325 & 0.51 & 0.06 \\
\hline & \begin{tabular}{|l|}
$\mathrm{N}$ \\
\end{tabular} & 138 & 138 & 138 & 138 & 138 & 138 \\
\hline \multirow[t]{3}{*}{1 (father+) } & Mean & 3.38 & 6.14 & 5.67 & 6.43 & 6.76 & 0.117 \\
\hline & Std. Deviation & 1.431 & 1.590 & 1.770 & 1.434 & 1.09 & 0.13 \\
\hline & $\mathrm{N}$ & 21 & 21 & 21 & 21 & 21 & 21 \\
\hline \multirow[t]{3}{*}{2 (mother + ) } & Mean & 3.11 & 6.67 & 6.56 & 5.89 & 7.00 & 0.099 \\
\hline & \begin{tabular}{|l|} 
Std. Deviation \\
\end{tabular} & 0.928 & 1.000 & 1.333 & 2.261 & 0.00 & 0.12 \\
\hline & $\mathrm{N}$ & 9 & 9 & 9 & 9 & 9 & 9 \\
\hline
\end{tabular}


Fruit consumption and fast-food products are significantly different from a statistical point of view $(\mathrm{p}<0.005)$ in relation to the parent's neophobia. Thus, fruit consumption is maximum in parents without neophobia, fast-food products consumption is high in children with neophobic fathers, and sweets consumption in high in mothers with neophobia (Table 9).

Food neophobia is defined as the reluctance to eat unfamiliar foods [7]. Numerous studies regarding neophobia have been carried out, but the mechanisms which determine food rejection have not yet been clearly identified [8]. Initially, a hypothesis was issued that in the genetic code of man there is the necessity to search the food source for the survival of the species, but he has to protect himself from potentially poisonous foods, thus limiting the diet, also known as "Omnivore's dilemma" [9-10]. Sensitive children and those with elevated sensory capacities can have a higher capacity to develop an eating disorder [11].

Genes influence behavioral traits during the childhood, including food behavior. Studies suggest that between 69 and $78 \%$ of the cases of neophobia are genetic in nature [12-13], while the rest are due to environmental factors.

Children are born with a biological predisposition for sweet foods and for the avoidance of bitter foods such as certain vegetables. Epidemiological data suggest that the mother's diet influences the flavor of breast milk, therefore children who are breastfed get familiarized early on with certain foods (plants, cereals, fruits, etc.) [14-15]. Food experiences of the future babies begin in utero, but only the infants who are breastfed are familiarized with various flavors by the repeated and continuous exposure to a large variety of flavors that takes place during breastfeeding. Thus, the food habits of children who have been breastfed are healthier compared to the food habits of children who have been fed formula [16].

The peak of food neophobia is between 2 and 5 years old, when children begin to explore the surrounding environment under the guidance of the parents, and it continues to drop during childhood, the teenage years and the mature years[17-18].Discussions with regard to the role played by sex or background in the onset of neophobia are contradictory and have not found a common ground.

The results of the studies suggest that everyday food preferences of children of preschool age are strongly associated to food neophobia, but not to age, sex, weight or breastfeeding history [19]. In other studies, neophobic mothers breastfeed for a shorter period of time, and the father's feeding was correlated with the duration of breastfeeding and the introduction of solid foods, [20] while Cooke's study from 2005 suggests there is a differentiation between the food preferences of girls and boys that have the same age [21]. The results of our study show that neophobia is present especially in girls and children whose mothers have a lower level of education, but it is not correlated with breastfeeding history, weight at birth or current weight.

Neophobia has a big impact on the quality of a diet [8]. The increase in food neophobia is associated with a reduced food variety and a poorer ,,index of healthy food“", due to the increase in discretionary foods (concentrated juices, fast-food products)[22- 23].Children present a higher degree of anxiety and negative reactivity to food. Food neophobia has been associated with lower preferences for all food groups, but especially for vegetables, fish and fruits $[3,5,24]$. They can also present deficits in the intake of proteins, monounsaturated fats, magnesium and vitamin $\mathrm{E}$ [22]. In our study, higher neophobia scores were associated with low consumption of fruits, dairy products and vegetables and an increase in the consumption of fast-food products. Furthermore, children's food neophobia was correlated with the presence of neophobia in one of the parents, which underlines the close relation between family history and food preferences, an idea that has been also suggested in the studies of Galloway AT [6, 25].

Individualized behavioral interventions, focused on early exposure to foods, could lead to the attenuation of food neophobia [26]. These interventions are counterproductive if the child is pressed to consume certain foods, and the parents feel frustrated [6,27].Children's fear of trying new foods was reduced by increasing the availability of such foods at home and having the parents tasting them [26, 28].

A limitation of this study is the fact that both children's food consumption and food neophobia have been valued by the parents, which leads to subjectivism. Thus, parents can report a higher consumption of discretionary foods than the real one, or they can answer more negatively about the child's availability to try new foods.

\section{Conclusions}

The results highlight the association of neophobia with a low consumption of fruits, dairy products and vegetables and an increase in the consumption of fast-food products, which indicates the necessity for the early detection of neophobia and early exposition of children to a large variety of nutrient foods. Furthermore, parents have to be educated with regards to the necessary strategies in order to overcome food neophobia and to promote models of healthy eating. 


\section{References}

1.LEANN L. BIRCH, JENNIFER O. FISHER. Development of Eating Behaviors Among Children and AdolescentsPediatrics, 1998 Mar;101(3 Pt 2):539

2.DOVEY TM, STAPLES PA, GIBSON EL, HALFORD JC.Food neophobia and 'picky/fussy' eating in children: a review. Appetite. 2008 MarMay;50(2-3):181-93. Epub 2007 Sep 29

3.MARIE DAMSBO-SVENDSEN, MICHAEL BOM FROST, ANNEMARIE OLSEN. A review of instruments developed to measure food neophobia. Appetite.Volume 113, 1 June 2017, Pages 358-367

4.LAURA VANDEWEGHE, LEENTJE VERVOORT, SANDRA VERBEKEN, ELLEN MOENS, and CAROLINE BRAET. Food Approach and Food Avoidance in Young Children: Relation with Reward Sensitivity and Punishment Sensitivity. Front Psychol. 2016; 7: 928. Published online 2016 Jun 24. doi: 10.3389/fpsyg.2016.00928

5.LUCY COOKE, S CARNELL, and J WARDLE . Food neophobia and mealtime food consumption in 4-5 year old children. Int J Behav Nutr Phys Act. 2006; 3: 14.

6.GALLOWAY AT, LEE Y, BIRCH LL. Predictors and consequences of food neophobia and pickiness in young girls. J Am Diet Assoc. 2003 Jun;103(6):692-8.

7.DOVEY TM, STAPLES PA, GIBSON EL, HALFORD JC. Food neophobia and 'picky/fussy' eating in children: a review. Appetite. 2008 Mar-May;50(2-3):181-93. Epub 2007 Sep 29.

8.LAFRAIRE J, RIOUX C, GIBOREAU A, PICARD D. Food rejections in children: Cognitive and social/environmental factors involved in food neophobia and picky/fussy eating behavior. Appetite. 2016 Jan 1;96:347-357

9.ARMELAGOS GJ. Brain evolution, the determinates of food choice, and the omnivore's dilemma. Crit Rev Food Sci Nutr. 2014;54(10):133041.

10. ROZIN P, VOLLMECKE TA. Food likes and dislikes. Annu Rev Nutr. 1986;6:433-456.

11.SOUTHALL A, C MARTIN. Feeding Problems in Children: A Practical Guide, Second Edition. CRC Press, 29 sept. 2017.374 pagini

12.COOKE LJ, HAWORTH CM, WARDLE J. Genetic and environmental influences on children's food neophobia. Am J Clin Nutr. 2007 Aug;86(2):428-33.

13.M S FAITH .Development and modification of child food preferences and eating patterns: behavior genetics strategies. International Journal of Obesity.2005 volume29, pages549-556

14.MENNELLA JA, DANIELS LM, REITER AR. Learning to like vegetables during breastfeeding: a randomized clinical trial of lactating mothers and infants.Am J Clin Nutr. 2017 Jul;106(1):67-76.

15. MENNELLA J.A., JAGNOW C.P., BEAUCHAMP G.K. Prenatal and postnatal flavor learning by human infants. Pediatrics. 2001;107:e88. doi: 10.1542/peds.107.6.e88

16.VENTURA AK. Does Breastfeeding Shape Food Preferences? Links to Obesity. Ann Nutr Metab. 2017;70 Suppl 3:8-15. doi: 10.1159/000478757. Epub 2017 Sep 14.

17.ADDESSI E, GALLOWAY AT, VISALBERGHI E, BIRCH LL. Specific social influences on the acceptance of novel foods in 2-5-year-old children. Appetite. 2005 Dec;45(3):264-71. Epub 2005 Oct 18

18.L.J. COOKE, J. WARDLE, E.L. GIBSON. Relationship between parental report of food neophobia and everyday food consumption in 2-6year-old children Appetite, 41 (2003), pp. 205-206.

19.RUSSELL CG, WORSLEY A. A population-based study of preschoolers' food neophobia and its associations with food preferences. J Nutr Educ Behav. 2008;40:11-19.

20.JENNI VAARNO , HARRI NIINIKOSKI , ANNE KALJONEN ,MINNA AROMAA .Mothers' restrictive eating and food neophobia and fathers' dietary quality are associated with breast-feeding duration and introduction of solid foods: the STEPS study. Public Health Nutritions. Volume 18, Issue 11,August 2015 , pp. 1991-2000

21.L.J. COOKE, J. WARDLE .Age and gender differences in children's food preferences. British Journal of Nutrition. 2005 ? 93 , pp. $741-746$ 22.FALCIGLIA GA, COUCH SC, GRIBBLE LS, PABST SM, FRANK R. Food neophobia in childhood affects dietary variety. J Am Diet Assoc. 2000 Dec;100(12):1474-81.

23.PERRY A.R , MALLAN M., KOO J, MAUCH C.E , DANIELS L.A, and MAGAREY A.M . Food neophobia and its association with diet quality and weight in children aged 24 months: a cross sectional studyInt J Behav Nutr Phys Act. 2015; 12 : 13.

24.OLIVEIRA A, JONES L, de LAUZON-GUILLAIN B, EMMETT P, MOREIRA P, CHARLES MA, LOPES C. Early problematic eating behaviours are associated with lower fruit and vegetable intake and less dietary variety at 4-5 years of age. A prospective analysis of three European birth cohorts. Br J Nutr. 2015 Sep 14;114(5):763-71.

25.FALCIGLIA GA, PABST S, COUCH S, GOODY C. Impact of parental food choices on child food neophobia. Children's Health Care. 2004;33:217-225.

26.BIRCH LL, MCPHEE L, SHOBA BC, PIROK E, STEINBERG L. What kind of exposure reduces children's food neophobia? Looking vs. tasting. Appetite. 1987 Dec;9(3):171-8.

27.A.T. GALLOWAY, L.M. FIORITO, L.A. FRANCIS, L.L. BIRCH.'Finish your soup': Counterproductive effects of pressuring children to eat on intake and affect. Appetite, 46 (2006), pp. 318-323

28.MYLES S. FAITH , MOONSEONG HEO, KATHLEEN L. KELLER , and ANGELO PIETROBELLI.Child food neophobia is heritable, associated with less compliant eating, and moderates familial resemblance for BMI.Obesity (Silver Spring). 2013 Aug; 21 (8): $1650-1655$.

$\overline{\text { Intrat in redactie: } 7.03 .2019}$ 